\title{
Psychological, ethical and deontological needs of the patients
}

\author{
Iryna Romash, Ivan Romash, Julia Barbanova, Tetiana Barbanova
}

Ivano-Frankivsk National Medical University, Ukraine

\section{Extended Abstract}

Keywords

Needs of the patients, doctor-patient relationship, patient safety, deontology.

Address for correspondence:

Iryna Romash, Department Propaedeutics of Internal Medicine, Ivano-Frankivsk National

Medical University, Ukraine. e-mail: iromash@ifnmu.edu.ua

This work is licensed under a Creative Commons Attribution-

NonCommercial 4.0 International License (CC BY-NC 4.0).

(c) (i) (8)

(C) Copyright: Romash , Romash , Barbanova, Barbanova, 2020

Submitted for publication: 21 July 2020

Received: 21 July 2020

Accepted for publication: 02 November 2020

Licensee NDSAN (MFC- Coordinator of the NDSAN), Italy

DOI http://doi.org/10.32437/mhgcj.v4i2.98

\section{Introduction}

We live in time of rapid technical development. And this in turn contributes to the formation of a technical approach to the doctor-patient relationship. The rapid and easily accessible flow of information, excessive awareness of patients sometimes complicates compliance - the cooperation of the doctor with the patient (Mandal, J., et.al., 2016 J. In world practice, compliance is considered excellent when the patient follows $75 \%$ of the doctor's instructions. In addition patient safety is a persistent issue in public health that has taken a new connotation in the contemporary sanitary context (Façanha, T. R.et.al., 2019).

\section{Purpose}

The purpose of the paper is to investigate what qualities a doctor of the 21st century should have from the point of view of a modern patient in order to improve compliance, cooperation of the doctor with the patient.

\section{Methodology.}

The survey was completely anonymous and voluntary. If the answer is yes, the patient had to choose from the proposed options the one that would most fully reflect his needs. In order to exclude subjectivity and systematic errors, the survey was conducted in various medical institutions of Ivano-Frankivsk. We interviewed 120 patients: 75 (group I) were hospitalized, 45 (group II) outpatient. The special questionnaire developed by us consists of 30 questions, which are grouped into groups, each of which reflects certain qualities: competence and personal experience of the doctor; review features; the ability to explain to the patient the essence of the disease; appearance.Some items of the questionnaire were: "Does age or gender of the doctor matter to you?"; "Did you have problems with" doctor's handwriting "? Did it in any way affect your cooperation with the doctor on the way to better health? ?". 


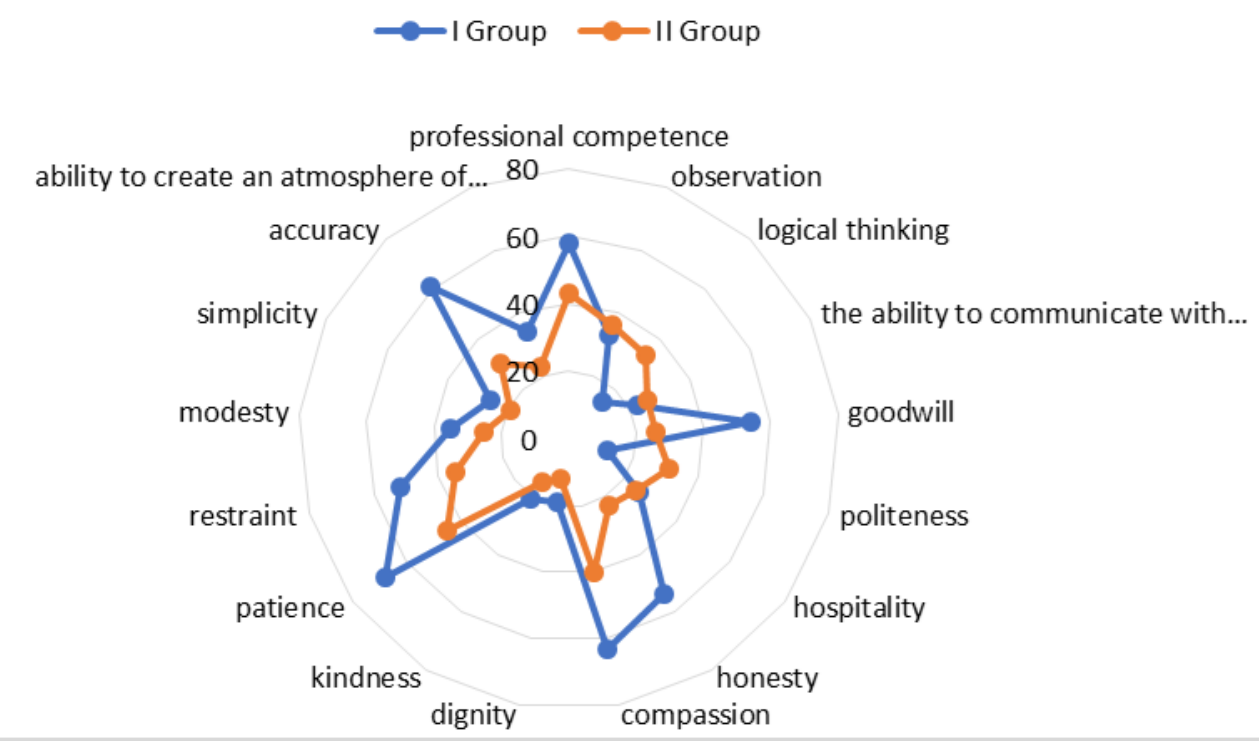

Figure 1. The distribution of the qualities of the doctor and the manifestation of the need for them among patients.

\section{Results and Discussion}

The study found that among the main qualities of the doctor, $88 \%$ of patients of group | and $80 \%$ of group || distinguish competence and professionalism; $42.66 \%$ vs $46.5 \%$ - attention; $60.0 \%$ vs $53.2 \%$ patience and kindness; $90.6 \%$ vs $80.0 \%$ the ability to easily and informatively answer questions of concern to the patient. The distribution of the qualities of the doctor and the manifestation of the need for them among the studied patients are shown in Figure 1.

Significantly fewer patients focused on the doctor's appearance or age. Significantly fewer patients focused on the doctor's appearance or age. However, there has been a trend: most respondents prefer middle-aged female doctors.

Causal analysis of the problem of poor handwriting of doctors showed the following data: $42.6 \%$ of patients of group I and $53.2 \%$ of group II complained of poor handwriting of doctors. And $6.6 \%$ and $2.2 \%$, respectively, consider it illegible. According to the patients, they had the experience of buying and even using drugs issued incorrectly in the pharmacy due to the "medical handwriting" of 5 patients of group
I and 1 patient of group II. However in the conditions of inpatient treatment this problem was quickly solved thanks to good cooperation of the doctor-nurse. It is almost impossible to control the same problem in the conditions of outpatient reception.

\section{Practical value}

The results of our study were successfully implemented in the educational and scientific process of the Department of Propaedeutics of Internal Medicine and the Department of Psychiatry, Narcology and Medical Psychology at Ivano-Frankivsk National Medical University and can be used in lectures and workshops on occupational therapy and rehabilitation, medical psychology, the psychology of creativity, general, pedagogical psychology, pedagogy, sociology, philosophy, etc.

\section{Conclusion}

The results of the study are statistically processed and allow to develop a model of the relationship between doctor and patient. It is possible that this study will promote better collaboration between physicians and patients. And medical students to think about what qualities should be nurtured in themselves for successful work. 


\section{Conflict of interest}

Authors declare no conflict of interests.

\section{References}

Mandal, J., Ponnambath, D. K., \& Parija, S. C. (2016). Utilitarian and deontological ethics in medicine. Tropical parasitology, 6(1),
7. https://doi. org/10.4103/22295070.175024

Façanha, T. R. D. S. \& Garrafa, V. (2019). Segurança do paciente e códigos deontológicos em Beauchamp e Childress. Revista bioética. Revista Bioética. doi:10.1590/1983- 